\title{
Optimasi Penempatan Lokasi Based Transceiver Station Menggunakan Flower Pollination Algorithm
}

\author{
Lailatur Rosyidah, Budi Setiyono, dan Suhud Wahyudi \\ Departemen Matematika, Fakultas Matematika dan Ilmu Pengetahuan Alam, Institut Teknologi \\ Sepuluh Nopember (ITS) \\ e-mail: masbudisetiyono@gmail.com
}

\begin{abstract}
Abstrak-Peningkatan jumlah pengguna sistem komunikasi seluler mengharuskan para penyedia layanan untuk memperluas jaringan demi kenyamanan konsumen. Salah satu komponen jaringan yang mendukung sistem komunikasi pemancar dan penerima sinyal adalah Based Transceiver Station (BTS). BTS mempunyai cakupan area tertentu yang dibatasi oleh suatu frekuensi tertentu. Pembangunan BTS bukanlah suatu hal yang mudah dan murah. Selain itu, penempatan BTS pun tidak bisa dilakukan secara sembarangan karena kondisi geografis serta estetika tata wilayah kota. Pada penelitian Tugas Akhir ini dilakukan optimasi penentuan lokasi BTS menggunakan Flower Pollination Algorithm (FPA). Hasil yang diperoleh menunjukkan bahwa FPA berhasil diterapkan untuk menentukan lokasi optimum BTS. Selain itu, hasil optimasi yang dilakukan menunjukkan bahwa semakin besar jumlah iterasi yang dilakukan belum tentu semakin baik pula nilai optimasi yang diperoleh
\end{abstract}

Kata Kunci-Sistem Komunikasi Seluler, Based Transceiver Station (BTS), Flower Pollination Algorithm (FPA).

\section{PENDAHULUAN}

UUMLAH Jumlah pengguna ponsel di Indonesia meningkat cukup signifikan. Pada tahun 2015 , data yang didapat dari US Cencus Bureau menyatakan bahwa pengguna ponsel di Indonesia telah melebihi 281 juta orang. Padahal jumlah penduduk Indonesia per awal tahun 2014 baru mencapai 251 juta jiwa. Sementara itu, dari data yang sama diketahui bahwa pengguna ponsel tersebut juga pengguna aktif internet [1]. Sebanyak 83,7 juta orang di Indonesia pada tahun 2014 merupakan pengguna internet menurut lembaga riset pasar emarketer. Angka tersebut menempatkan Indonesia pada peringkat ke-6 terbesar di dunia dalam hal jumlah pengguna internet [2]. Sedangkan pada tahun 2016, menurut survei yang dilakukan oleh Asosiasi Penyelenggara Jaringan Internet Indonesia (APJII) diketahui bahwa 132,7 juta orang di Indonesia telah terhubung ke internet. Hal ini berarti lebih dari setengah penduduk Indonesia kini menggunakan internet dimana total penduduk Indonesia adalah 256,2 juta orang [3]. E-Marketer juga memperkirakan bahwa pada tahun 2018, sebanyak 3,6 milyar penduduk dunia akan mengakses internet setidaknya satu kali setiap bulan.

Peningkatan jumlah pengguna jasa telekomunikasi yang cukup signifikan tersebut mengharuskan para penyedia layanan untuk memperluas jaringan demi kenyamanan konsumen. Perluasan jaringan setiap penyedia layanan telekomunikasi juga tidak serta-merta dapat direalisasikan dengan mudah karena dibutuhkan pembangunan infrastruktur yang mendukung. Salah satu komponen jaringan yang mendukung sistem komunikasi pemancar dan penerima sinyal dinamakan Based Transceiver Station (BTS).

BTS mempunyai cakupan area tertentu yang dibatasi oleh frekuensi tertentu. Pembangunan BTS bukanlah suatu hal yang mudah dan murah. Selain itu, penempatan BTS pun tidak bisa dilakukan secara sembarangan karena kondisi geografis serta estetika tata wilayah kota. Oleh karena itu, dalam penelitian Tugas Akhir ini dilakukan optimasi penentuan lokasi BTS menggunakan Flower Pollination Algorithm (FPA).

\section{TINJAUAN PUSTAKA}

\section{A. Sistem Komunikasi Seluler}

Sistem komunikasi seluler merupakan suatu sistem komunikasi jarak jauh tanpa menggunakan kabel. Sistem ini semakin diperlukan sejak pengguna komunikasi seluler memiliki mobilitas yang tinggi dan membutuhkan alat telekomunikasi yang siap digunakan kapanpun dan dimanapun. Bentuk jaringan dari sistem ini berkaitan dengan luas daerah pelayanan yang dimodelkan dalam bentuk hexagonal karena bentuk ini merupakan bentuk yang paling optimal [4]. Bentuk hexagonal menyebabkan susunan sel menjadi beraturan dan simetris seperti ditunjukkan pada Gambar 2.1 [5].

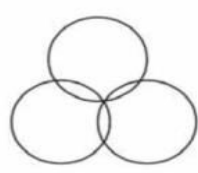

SEL IDEAL

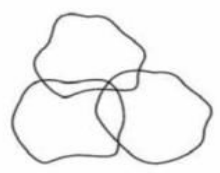

SEL REAL

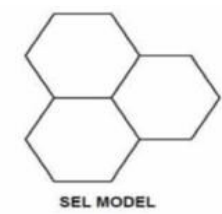

SEL MODEL
Gambar 1. Bentuk pemodelan sel.

Gambar 2. Daerah pancaran sinyal.

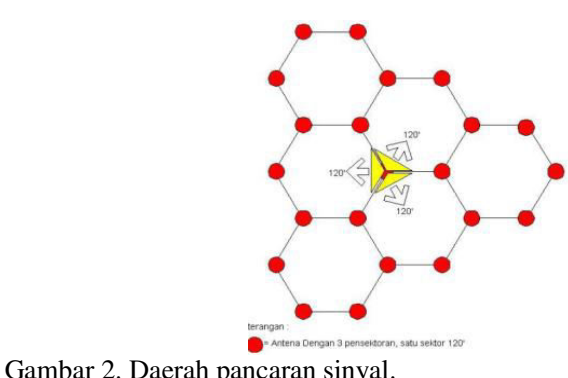


Sebuah sel hexagonal dapat dibentuk dengan menggunakan enam buah transceiver yang menggunakan antena dengan enam penyektoran dimana setiap sektor akan membentuk daerah pancaran sebesar $120^{\circ}$ dapat dilihat pada Gambar 2.2. Selain itu, hexagonal dibentuk oleh 6 buah segitiga sama sisi sehingga jarak sisi-sisinya akan sama panjang dengan jarak jari-jarinya. Hal ini dapat menghindari masalah blank spot dan overlap coverage [6].

\section{B. Mobile Station}

Mobile Station (MS) merupakan perangkat radio yang dapat berkomunikasi dengan jaringan GSM. MS terdiri dari Mobile Equipment (ME) dan Subscriber Identity Module (SIM). SIM merepresentasikan identitas pelanggan terhadap jaringan sehingga ME hanya dapat melakukan emergency calls jika tanpa adanya SIM. ME teridentifikasi oleh IMEI (International Mobile Equipment Identity) tertentu sedangkan SIM card dilindungi oleh suatu mekanisme Personal Identity Number (PIN) yang dimiliki setiap user [5]. MS membantu jaringan dalam mengukur kualitas sinyal radio untuk menentukan handover [7].

\section{Based Station Subsystem}

BSS merupakan komponen jaringan sistem GSM yang menyediakan jalur koneksi antara MS dengan MSC (Mobile Service Switching Centre). Secara umum, BSS terdiri dari dua komponen utama yaitu :

1. Base Station Controller (BSC)

2. Base Transceiver Station (BTS)

BSC merupakan penghubung antara BTS dengan MSC, dimana satu BSC dapat terhubung dengan beberapa BTS. BSC digunakan untuk mengontrol BTS yang ada dibawahnya serta sebagai manajemen BSS. BSC menangani radio-channel setup, frequency hopping, handover dari BTS ke BTS (kecuali pada inter-MSC-handover dimana pengontrolan berada pada tanggung jawab MSC) [7].

Fungsi penting BSC yakni sebagai konsentrator dimana berbagai koneksi berkecepatan rendah yang terhubung ke BTS akan berkurang sampai sejumlah kecil koneksi yang menuju MSC. BSC menyediakan informasi yang dibutuhkan untuk Network Management Subsystem (NMS). BSC juga menyimpan database untuk semua tempat, termasuk informasi seperti frekuensi pembawa, daftar frekuensi hopping, level pengurangan daya, dan penerimaan sinyal untuk perhitungan batas sel. Data ini diperoleh langsung dari bagian perencanaan radio yang menyertakan pemodelan dari propagasi sinyal begitu pun dengan proyeksi traffic [7].

BTS merupakan perangkat GSM yang terhubung langsung dengan MS melalui air interface atau disebut juga Um interface. BTS berfungsi sebagai komponen pengirim dan penerima (transceiver) sinyal komunikasi dari atau ke MS. Sebuah BTS dapat melakukan coverage area sejauh $35 \mathrm{~km}$. Area cakupan ini dinamakan dengan sel dimana setiap sel dapat dibentuk oleh sebuah BTS atau lebih bergantung pada bentuk sel [6].

Fungsi dasar BTS adalah sebagai Radio Resource Management yaitu melakukan fungsi-fungsi yang terkait dengan mengontrol power yang ditransmisikan ke MS dan turut serta mengontrol proses handover [6].

\section{Konsep Seluler}

Salah satu hal yang mendasari perlu adanya perkembangan sistem komunikasi seluler adalah faktor keterbatasan spectrum frekuensi dan upaya penggunaan frekuensi secara efisien. Pada sistem komunikasi seluler daerah pelayanan akan dibagi menjadi daerah-daerah yang disebut sel dimana model dari suatu sel merepresentasikan cakupan area dari suatu base station. Pembagian ini memungkinkan menara transmitter dengan daya pancar dan ketinggian yang lebih rendah dibanding sistem komunikasi generasi sebelumnya sehingga dapat menekan biaya [5].

Pembagian area dalam kumpulan sel-sel adalah prinsip penting GSM sebagai sistem telekomunikasi selular. Setiap sel mengacu pada satu frekuensi tertentu. Pada kenyataannya jumlah frekuensi yang dialokasikan terbatas, sementara jumlah sel bisa saja berjumlah sangat banyak. Oleh karena itu, dilakukan teknik pengulangan frekuensi (frequency re-use) [7].

Frequency reuse adalah penggunaan ulang suatu frekuensi pada suatu sel dimana frekuensi tersebut sudah digunakan pada sel lain. Jarak antara dua sel dengan frekuensi yang sama harus diatur agar tidak terjadi interferensi. Konsep ini merupakan konsep inti dari sistem radio seluler. Pada konsep ini, pengguna di lokasi sel yang berbeda dapat menggunakan kanal frekuensi yang berbeda secara simultan diluar jangkauan interferensinya. Sistem frequency reuse dapat meningkatkan efisiensi spectrum namun jika sistem tidak didesain dengan teliti maka akan terjadi interferensi yang serius [5].

Interface antara BTS dan MS secara uplink maupun downlink pada GSM diakses melalui TDMA digital. Kanal pembicaraan atau data untuk pelanggan diberikan melalui TS (time slot) dimana satu modul transceiver (TRX) dapat memberikan delapan kanal fisik (0 sampai 7) [5]. Pada prakteknya tidak semua kanal TDMA tersebut bisa digunakan untuk kanal pembicaraan $(\mathrm{TCH}=$ Traffic Channel). Oleh karena itu, dalam sebuah BTS juga diperlukan SDCCH (Stand-alone Dedicated Control Channel) yang digunakan untuk call setup dan location updating serta BCCH (Broadcast Control Channel) yang merupakan kanal downlink yang memberikan informasi dari BTS ke MS mengenai jaringan, sel yang kedatangan panggilan, dan sel-sel di sekitarnya [7].

\section{E. Flower Pollination Algorithm}

Penyerbukan dapat didefinisikan sebagai perpindahan serbuk sari ke kepala putik. Perpindahan serbuk ini bisa terjadi dengan bantuan penyerbuk seperti burung, serangga, dan hewan lain. Penyerbukan terdiri dari dua macam yakni penyerbukan sendiri dan penyerbukan silang. Penyerbukan sendiri terjadi jika serbuk sari dari satu bunga jatuh pada bunga tersebut atau bunga lain pada tumbuhan yang sama. Sedangkan penyerbukan silang terjadi jika serbuk sari dari satu bunga jatuh pada kepala putih tumbuhan yang berbeda.

Flower Pollination Algorithm (FPA) adalah algoritma yang terinspirasi dari alam khususnya pada tumbuhan berbunga. Pada tahun 2012, Xin-She Yang memberikan gagasan tentang lokalisasi ini. Bunga digunakan untuk reproduksi pada spesiesnya melalui proses penyerbukan [8].

Terdapat empat kaidah dari penyerbukan yang kemudian disusun sebagai dasar dari FPA. 
Penyerbukan silang terjadi apabila serbuk sari jatuh dari bunga yang berasal dari tanaman yang berbeda. Penyerbukan ini mengikuti aturan dari Levy distribution dengan melompat atau terbang dengan jarak yang jauh. Hal ini dikenal dengan proses penyerbukan global

Penyerbukan sendiri terjadi apabila serbuk sari yang jatuh berasal dari bunga yang sama atau bunga yang lain dari tanaman yang sama. Proses ini dinamakan penyerbukan local

Flower constancy adalah kumpulan penyerbuk dan tipe bunga. Hal ini merupakan suatu peningkatan dari proses penyerbukan bunga.

Penyerbukan lokal dan penyerbukan global dikontrol oleh suatu nilai antara 0 sampai 1 yang disebut switch probability [8].

Pada FPA, terdapat dua langkah kunci yaitu penyerbukan global dan local. Pada penyerbukan global kaidah pertama dan ketiga digunakan bersama-sama untuk menemukan solusi pada langkah selanjutnya $\left(x_{i}{ }^{t+1}\right)$ menggunakan nilai dari langkah sebelumnya $\left(x_{i}{ }^{t}\right)$. Penyerbukan global diformulasikan pada persamaan (1)

$$
x_{i}^{t+1}=x_{i}{ }^{t}+L\left(x_{i}^{t}-g^{*}\right)
$$

Subscript i menunjukkan serbuk ke-i (atau bunga) dan persamaan (1) diterapkan untuk serbuk pada bunga. $\mathrm{g}^{\wedge *}$ adalah solusi terbaik saat itu. L adalah jarak terbang yang didapat dari Levy distribution. Sedangkan pada penyerbukan local menggunakan kaidah ketiga tentang flower constancy ditunjukkan pada persamaan (2)

$$
x_{i}^{t+1}=x_{i}^{t}+\varepsilon\left(x_{j}^{t}-x_{k}^{t}\right)
$$

dimana $x_{j}{ }^{t}$ dan $x_{k}{ }^{t}$ adalah solusi dari tanaman yang berbeda. $\varepsilon$ adalah angka acak antara 0 dan 1 . Berdasarkan keempat kaidah tersebut, switch probability (p) digunakan untuk memilih tipe penyerbukan yang akan mengontrol proses optimasi pada iterasi.

\section{METODE PENELITIAN}

Tahapan yang dilakukan pada implementasi algoritma ini ditunjukkan pada Gambar 3.

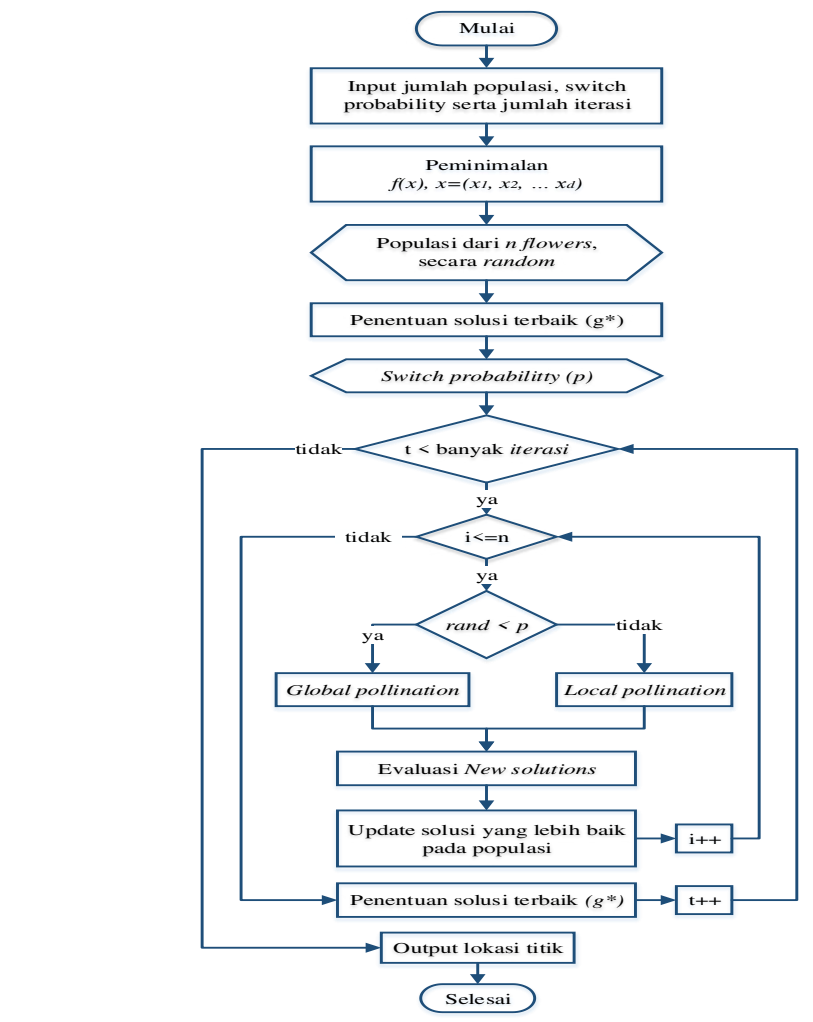

Gambar 3. Diagram alir penelitian.

\section{PERANCANGAN OPTIMASI BTS}

Pada bab ini menjelaskan mengenai perancangan implementasi sebagai acuan implementasi system

\section{A. Perancangan Algoritma}

Penerapan Flower Pollination Algortihm pada penelitian ini dijelaskan pada langkah-langkah berikut :

1. Memodelkan fungsi obyektif sedemikian hingga meminimalkan jumlah BTS.

2. Inisialisasi jumlah populasi, switch probability dan jumlah iterasi

3. Menentukan solusi terbaik dari setiap populasi

4. Membandingkan nilai random dengan switch probability

5. Jika nilai random kurang dari switch probability maka akan dilakukan local pollination. Jika tidak maka akan dilakukan global pollination

6. Melakukan update solusi terbaik

7. Mengulangi langkah 4-6 sebanyak jumlah populasi

8. Melakukan iterasi selanjutnya dengan mengulangi langkah 4-7 sebanyak jumlah iterasi

9. Menentukan solusi terbaik

Berdasarkan langkah-langkah tersebut akan dilakukan perhitungan sebagai berikut :

1. Proses memodelkan fungsi obyektif sedemikian hingga meminimalkan banyaknya BTS. Berdasarkan kondisi tersebut maka didapatkan fungsi optimasi yang ditunjukkan pada persamaan (1). 


$$
z=\left(\sum_{i=1}^{n}\left\lfloor\frac{d\left(m_{i}, b\right)}{r}\right\rfloor\right)+k
$$

dimana,

$$
\begin{array}{lll}
Z & =\text { fungsi optimasi } \\
n & =\text { banyak mobile station } \\
m_{i} & =\text { lokasi mobile station ke- } i \\
b & =\text { lokasi BTS terdekat dengan mobile } \\
& \text { station ke- } i \\
r & =\text { radius setiap BTS } \\
k & =\text { banyak BTS } \\
d\left(m_{i}, b\right) & =\begin{array}{l}
\text { jarak antara mobile station ke- } i \text { dan BTS } \\
\end{array} & \text { terdekat }
\end{array}
$$

Untuk menentukan jarak antara mobile station dan BTS digunakan rumus Euclidean yang ditunjukkan pada persamaan (2) [9].

$$
d\left(m_{i}, b\right)=\sqrt{\left(x_{p}-x_{q}\right)^{2}+\left(y_{p}-y_{q}\right)^{2}}
$$

dimana,

$$
\begin{array}{lc}
m_{i} & =\left(x_{p}, y_{p}\right) \\
b & =\left(x_{2}, y_{2}\right) \\
x_{p} & =\text { koordinat } \mathrm{x} \text { dari } m_{i} \\
y_{p}=\text { koordinat } \mathrm{y} \text { dari } m_{i} \\
x_{q}=\text { koordinat } \mathrm{x} \text { dari } b \\
y_{q}=\text { koordinat } \mathrm{y} \text { dari } b
\end{array}
$$

Berikut merupakan contoh perhitungan menggunakan persamaan (3). Misal terdapat lima mobile station pada suatu area dengan nilai $d\left(m_{1}, b\right)=4 ; d\left(m_{2}, b\right)=$ $7 ; d\left(m_{3}, b\right)=12 ; d\left(m_{4}, b\right)=9 ; d\left(m_{5}, b\right)=15$

Diberikan radius BTS sebesar 10 dan banyak BTS adalah satu sehingga diperoleh perhitungan sebagai berikut :

$z=\left(\sum_{i=1}^{n}\left\lfloor\frac{d\left(m_{i}, b\right)}{r}\right\rfloor\right)+k$

$=\left(\left\lfloor\frac{d\left(m_{1}, b\right)}{r}\right\rfloor+\left\lfloor\frac{d\left(m_{2}, b\right)}{r}\right\rfloor+\cdots+\left\lfloor\frac{d\left(m_{5}, b\right)}{r}\right\rfloor\right)+1$

$=\left(\left\lfloor\frac{4}{10}\right\rfloor+\left\lfloor\frac{7}{10}\right\rfloor+\left\lfloor\frac{12}{10}\right\rfloor+\left\lfloor\frac{9}{10}\right\rfloor+\left\lfloor\frac{15}{10}\right\rfloor\right)+1$

$=(0+0+1+0+1)+1$

$$
=3
$$

Nilai $z$ yang didapatkan bergantung pada jarak antar mobile station dan BTS terdekat serta banyak BTS pada suatu area. Semakin jauh jarak mobile station dari BTS terdekat maka akan semakin besar nilai $z$. Namun hal ini dapat diimbangi dengan menambah banyak BTS yaitu nilai $k$ sehingga jarak antara mobile station dan BTS bisa lebih dekat sehingga nilai $z$ bisa lebih kecil.

2. Proses Inisialisasi lokasi mobile station, banyak BTS, banyak populasi, banyak iterasi, switch probability, luas area serta radius.

Misalkan inisilisasi yang digunakan yaitu :

Jumlah BTS = 3

Jumlah mobile station $=9$

Jumlah populasi $=3$

Jumlah iterasi $=100$

Switch probability $\quad=0.7$
Luas Area $=30 \times 30$

Radius $=10$

Inisialisasi mobile station populasi ke-1 ditunjukkan pada Tabel 1 sedangkan inisialisasi titik BTS ditunjukkan pada Tabel 2

Tabel 1.

Inisialisasi titik mobile station

\begin{tabular}{ccc}
\hline \hline ms ke & $\mathrm{x}$ & $\mathrm{y}$ \\
\hline 1 & 5 & 5 \\
2 & 5 & 15 \\
3 & 5 & 25 \\
4 & 15 & 5 \\
5 & 15 & 15 \\
6 & 15 & 25 \\
7 & 25 & 5 \\
8 & 25 & 15 \\
9 & 25 & 25 \\
\hline \hline
\end{tabular}

3. Proses penentuan solusi terbaik dari setiap populasi.

\begin{tabular}{|c|c|c|c|c|c|}
\hline \multirow[b]{2}{*}{$\begin{array}{l}\text { MS } \\
\text { ke- }\end{array}$} & \multicolumn{3}{|c|}{ BTS ke- } & \multirow{2}{*}{$\mathrm{min} / \mathrm{rad}$} & \multirow{2}{*}{ floor } \\
\hline & 1 & 2 & 3 & & \\
\hline 1 & 15.81139 & 11.18034 & 21.63331 & 1.118034 & 1 \\
\hline 2 & 7.071068 & 11.18034 & 18.11077 & 0.707107 & 0 \\
\hline 3 & 7.071068 & 18.02776 & 19.69772 & 0.707107 & 0 \\
\hline 4 & 15.81139 & 5 & 14.42221 & 0.5 & 0 \\
\hline 5 & 7.071068 & 5 & 8.246211 & 0.5 & 0 \\
\hline 6 & 7.071068 & 15 & 11.31371 & 0.707107 & 0 \\
\hline 7 & 21.2132 & 11.18034 & 12.16553 & 1.118034 & 1 \\
\hline 8 & 15.81139 & 11.18034 & 2.828427 & 0.282843 & 0 \\
\hline 9 & 15.81139 & 18.02776 & 8.246211 & 0.824621 & 0 \\
\hline
\end{tabular}
Solusi terbaik diperoleh dari perhitungan terhadap fungsi optimasi. Fungsi ini melakukan perhitungan terhadap setiap titik BTS dan mobile station pada populasi. Nilai yang dihasilkan dari fungsi tersebut merupakan nilai minimum dari setiap populasi. Misalkan untuk populasi ke-1 digunakan inisialisasi titik BTS seperti ditunjukkan pada Tabel 4.2

Tabel 2.

Inisialisasi titik BTS populasi ke-1

\begin{tabular}{ccc}
\hline \hline BTS ke- & $\mathrm{x}$ & $\mathrm{y}$ \\
\hline 1 & 10 & 20 \\
2 & 15 & 10 \\
3 & 23 & 17 \\
\hline \hline
\end{tabular}

Tabel 1 dan Tabel 2 digunakan untuk melakukan perhitungan dengan fungsi optimasi pada persamaan 3 seperti ditunjukkan pada Tabel 3. Untuk mendapatkan jarak antara mobile station dan BTS digunakan Persamaan (4).

Tabel 3.

Perhitungan fungsi optimasi

Berdasarkan pada Tabel 3 diperoleh nilai $z=5$. Selanjutnya, dihitung juga nilai $z$ pada setiap populasi. Setiap populasi mempunyai inisialisasi lokasi BTS yang berbeda sehingga mempunyai jarak yang berbeda pula. Misalkan 
lokasi BTS pada populasi ke-2 ditunjukkan pada Tabel 4 dan lokasi BTS pada populasi ke-3 ditunjukkan pada Tabel 5

Tabel 4.

Inisialisasi titik BTS populasi ke-2

\begin{tabular}{ccc|}
\hline \hline BTS ke- & $\mathrm{x}$ & $\mathrm{y}$ \\
\hline 1 & 5 & 13 \\
2 & 15 & 20 \\
3 & 21 & 25 \\
\hline \hline
\end{tabular}

Tabel 5.

Inisialisasi titik BTS populasi ke-3

\begin{tabular}{ccc}
\hline \hline BTS ke- & $\mathrm{x}$ & $\mathrm{y}$ \\
\hline 1 & 10 & 10 \\
2 & 17 & 23 \\
3 & 25 & 13 \\
\hline \hline
\end{tabular}

Inisialisasi lokasi BTS tersebut digunakan untuk menghitung nilai minimum dari setiap populasi. Hasil perhitungan nilai minimum dari ketiga populasi tersebut ditunjukkan pada Tabel 6.

Tabel 6.

Hasil perhitungan nilai minimum setiap populasi

\begin{tabular}{cc}
\hline \hline Populasi ke- & Z \\
\hline 1 & 5 \\
2 & 7 \\
3 & 4 \\
\hline \hline
\end{tabular}

Berdasarkan Tabel 6 dapat diketahui bahwa pada populasi ke-3 didapat nilai minimum dari seluruh populasi.

4. Proses membandingkan nilai random dengan switch probability. Setiap populasi mendapatkan nilai random yang berada pada range $[0,1]$. Berikut merupakan contoh nilai random pada populasi ke-1.

Tabel 7

Nilai random pada populasi ke-1

\begin{tabular}{ccc}
\hline \multicolumn{3}{c}{ Nilai random pada populasi ke- } \\
\hline BTS ke- & random & pollination \\
\hline 1 & 0.4 & local \\
2 & 0.8 & global \\
3 & 0.9 & global \\
\hline
\end{tabular}

5. $\overline{\text { Jika nilai random kurang dari nilai switch probability }}$ maka akan dilakukan proses Local Pollination. Proses ini dijalankan menggunakan persamaan (2). Jika nilai random lebih dari nilai switch probability maka akan dilakukan proses Global Pollination. Proses ini dijalankan menggunakan persamaan (1). Nilai Levy Distribution digunakan untuk menentukan jarak terbang serangga. Perhitungan ini membutuhkan langkah-langkah yang sangat banyak sehingga nilai Levy Distribution diubah menjadi bilangan acak yang berada pada range 0 sampai 1 [9]. Hasil perhitungan titik-titik pada populasi ke-1 ditunjukkan pada Tabel 4.8. Populasi ke-2 dan ke-3 juga dilakukan perhitungan sesuai sehingga mendapatkan titik-titik baru hasil optimasi.

Tabel 8.

Hasil perhitungan titik populasi ke-1

\begin{tabular}{ccc}
\hline \hline BTS ke- & x2 & y2 \\
\hline
\end{tabular}

\begin{tabular}{ccc}
\hline 1 & 6.8 & 17.2 \\
2 & 13.4 & 20.4 \\
3 & 21.2 & 20.6 \\
\hline \hline
\end{tabular}

6. Proses penentuan solusi terbaik. Solusi terbaik diperoleh untuk setiap populasi di setiap iterasi. Setiap solusi dibandingkan sampai mendapatkan solusi terbaik. Perbandingan hasil nilai minimum dari setiap populasi ditunjukkan pada Tabel 9.

Tabel 9.

Perbandingan hasil nilai minimum dari setiap populasi

\begin{tabular}{ccc}
\hline \hline $\begin{array}{c}\text { Populasi } \\
\text { ke- }\end{array}$ & sebelum & sesudah \\
\hline 1 & 5 & 6 \\
2 & 7 & 7 \\
3 & 4 & 3 \\
\hline \hline
\end{tabular}

Berdasarkan tabel tersebut dapat diketahui bahwa pada populasi ke-3 diperoleh nilai minimum dengan nilai $\mathrm{z}=3$.

7. Proses pengulangan langkah 4-6. Proses ini dijalankan sebanyak jumlah populasi. Semakin banyak jumlah populasi maka akan semakin banyak kemungkinan untuk mencapai nilai minimum.

8. Proses pengulangan langkah 4-7 sebanyak jumlah iterasi. Jumlah iterasi yang dimaksud adalah jumlah iterasi maksimum. Jika nilai minimum sudah tercapai sebelum iterasi maksimum maka perhitungan akan berhenti pada iterasi terakhir yang dijalankan. Nilai minimum dicapai ketika jumlahan perbandingan jarak mobile station dan BTS terdekat sama dengan nol dengan jumlah BTS paling sedikit.

9. Proses penentuan solusi terbaik. Berdasarkan pada Tabel 9 didapatkan nilai minimum pada populasi ke-3 dengan titik-titik yang ditunjukkan pada Tabel 10 .

Tabel 10.

Titik-titik hasil optimasi populasi ke-3

\begin{tabular}{ccc}
\hline \hline BTS ke- & $\mathrm{x}$ & $\mathrm{y}$ \\
\hline 1 & 9.76 & 10.3 \\
2 & 14 & 22.4 \\
3 & 25 & 13 \\
\hline \hline
\end{tabular}

\section{B. Perancangan Plotting Titik}

Perancangan plotting titik dilakukan untuk mengetahui secara visual posisi BTS dan mobile station sebelum dan sesudah dilakukan optimasi. Lokasi BTS dan mobile station sebelum dilakukan optimasi ditunjukkan pada Gambar 4 sedangkan lokasi BTS dan mobile station sesudah dilakukan optimasi dtunjukkan pada Gambar 5. 


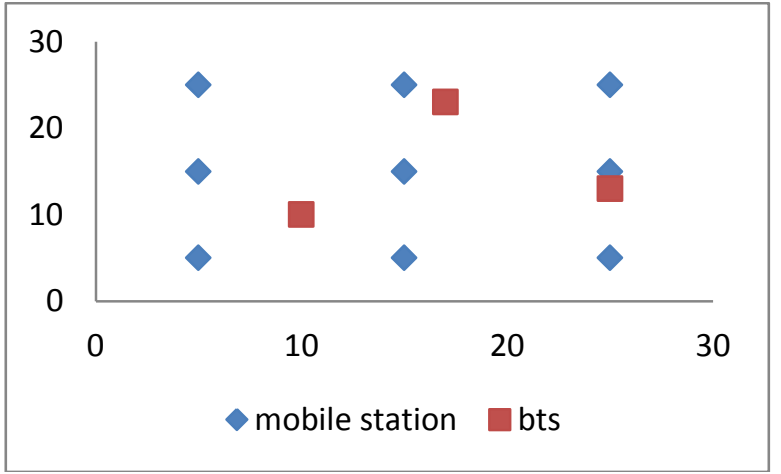

Gambar 4. Lokasi BTS dan mobile station sebelum dioptimasi.

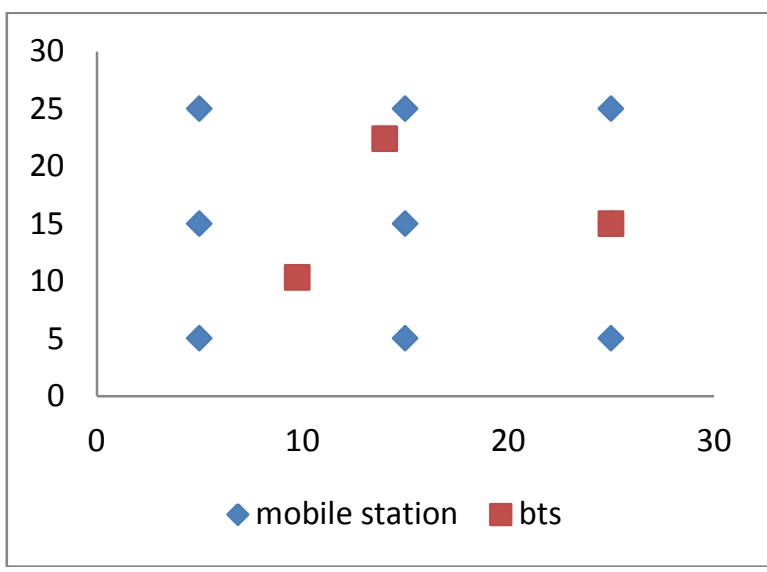

Gambar 5. Lokasi BTS dan mobile station setelah dioptimasi.

Titik berwarna biru merupakan lokasi sebaran mobile station sedangkan titik berwarna merah merupakan lokasi BTS. Berdasarkan Gambar 4 BTS dengan radius sebesar 10 dapat diketahui bahwa terdapat satu mobile station yang tidak tercover. Sedangkan pada Gambar 5 dengan radius yang sama semua mobile station dapat tercover.

\section{KESIMPULAN}

Berdasarkan analisis terhadap hasil pengujian program, maka dapat diambil kesimpulan sebagai berikut:

1. Flower Pollination Algorithm telah berhasil diterapkan untuk menentukan lokasi optimasi Based Transceiver Station.

2. Hasil optimasi pada Flower Pollination Algorithm menunjukkan bahwa semakin besar jumlah iterasi yang dilakukan belum tentu semakin baik nilai optimasi yang didapatkan

\section{DAFTAR PUSTAKA}

[1] Bursadana, "Jumlah Pengguna Ponsel di Indonesia," 2016. [Online]. Available: http://media.bursadana.co.id/2016/03/18.

[2] Kementerian Komunikasi dan Informatika, "Pengguna Internet Indonesia Nomor Enam Dunia." [Online]. Available: https://www.kominfo.go.id/content/detail/ 4286/pengguna-internetindonesia-nomor-enam-dunia/0/sorotan_media. [Accessed: 16-Jan-2018].

[3] Kompas, "Pengguna Internet di Indonesia Capai 132 Juta," 2016. [Online]. Available: http://tekno.kompas.com/read/2016/10/24/.

[4] A. Arif and A. Mauludiyanto, "Optimasi Peletakan Base Transceiver Station di Kabupaten Mojokerto menggunakan Algoritma Differential Evolution," J. ITS, 2015.

[5] Z. Askar, "Aplikasi Sistem Manajemen Trafik Hierarchical Cell Structure di Area Depok," Depok, 2009.

[6] Yumpu, "No Title." [Online]. Available: https://www.yumpu.com/id/document/view/ 15686980/cominet-v10/1.

[7] Y. Pramsistya, D. B. Utomo, and M. I. Irawan, "Optimasi Penempatan BTS dengan Menggunakan Algoritma Genetika," J. Sain dan Seni, vol. 1, no. $1,2010$.

[8] R. Kaur and A. Kumar, "An Approach for Selecting Optimum Number of Base Stations and Optimizing Site Locations using Flower Pollination Algorithm," Int. J. Comput. Appl., 2016.

[9] Pbarrett.net., Euclidian Distance. Raw, normalized, and double-scaled coefficients. The Technical whitepaper series, 2005. 